\title{
Инжекция воды в бензиновых двигателях внутреннего сгорания в Республике Саха (Якутия)
}

\author{
Дегтярев А.В., студент, \\ «Северо-Восточный федеральный университет имени М.К. Аммосова», \\ Автодорожный факультет \\ 2. Якутск \\ E-mail: aytal14031998@gmial.com
}

Научный руководитель: Стариий преподаватель каф. «ЭАТиАС» Андреев С.В.

Система впрыска воды в двигатель является одним из доступных способов тюнинга силового агрегата. Данное решение позволяет увеличить мощность, крутящий момент и экономичность ДВС, повысить детонационную стойкость и улучшить ряд других характеристик мотора. При этом такой тюнинг не предполагает каких-либо серьезных доработок силового агрегата по «железу», то есть впрыск воды в инжекторный двигатель или карбюраторный мотор может быть установлен с минимальным вмешательством в конструкцию. [1]

Идея впрыска воды в ДВС была изобретена H. Ricardo в 1930 году, который продемонстрировал, как можно удвоить мощность двигателя, используя подачу воды и метанола в двигатель. Технология широко применялась во время Второй мировой войны в радиальных авиационных двигателях американских и немецких самолетов для кратковременного форсажа. [1,2,3]

Цель данной работы: изучить состояние вопроса с впуском воды в камеру сгорания ДВС

Исходя из этого были поставлены следующие задачи:

- Изучить процесс впуска воды в бензиновых двигателях ДВС

- Ознакомиться с оборудованием впрыска воды

- Выявить положительные и отрицательные стороны данного процесса

- Экономическую целесообразность

• Экологические аспекты

Принцип работы системы впрыска воды основан на свойстве огромной теплоемкости воды. Если воду распылить и мелкие капельки воды запустить в двигатель вместе с впускным воздухом, то они охладят и воздух, попадающий в двигатель, и сам впускной коллектор. Есть мнение, что микрочастицы воды позволяют сделать смесь бензина и топлива более однородной, что повышает КПД. Попадая в горячую камеру сгорания (300-600С) маленькие капли воды моментально испаряются, превращаясь в пар который очищает камеру сгорания, днище поршня и свечи, а также "давит" на поршень, т.к. вода расширяется при испарении в 1700 раз от своего объема в жидком виде. Т.е. вода создает паровой эффект в двигателе внутреннего сгорания, который выражается в повышении крутящего момента двигателя. Более того, вода вступает в химическую реакцию с выхлопными газами, что сильно снижает количество вредных выбросов, а значит это экологичная технология.

Впрыск воды экстремально увеличивает детонационную стойкость топлива, это значит, что можно использовать более дешевое топливо без вреда для двигателя. 
Получается, что с впрыском воды можно заправлять вместо 98го бензина 92й, а двигатель даже не заметит подмены, при этом финансовая выгода на лицо.

При применении впрыска воды можно увеличивать давление наддува турбированных двигателей и получать больше мощности, так как вода эффективно снижает температуру выхлопных газов, а это положительно влияет на ресурс турбины и выхлопного тракта.

Впрыск воды позволяет экономить топливо, исходя из всех вышеописанных фактов, получается, что водителю придется меньше давить на педаль газа, чтобы ускоряться так же быстро, а значит расход топлива будет неуклонно снижаться. По данным исследований расход топлива снижается от 10 до 20\%, в зависимости от типа и мощности ДВС.

Следует обратить внимание на то, что оптимально подавать в мотор не просто дистиллированную воду, а смесь спирта и воды в соотношении 1/1. Такая водноспиртовая добавка лучше распыляется, в итоге образуется мелкодисперсная смесь из воды, воздуха, спирта и бензина. Если вода позволяла, главным образом, уменьшить детонацию и лучше охлаждать смесь, наличие в смеси метанола обеспечило ряд дополнительных преимуществ.

Плюсы от применения впрыска воды:

- снижение температуры впускного воздуха;

- снижение температуры в камере сгорания;

- резкое повышение детонационной стойкости топлива (в том числе некачественного и низкооктанового);

- снижение вредных выбросов на 60-80\%;

- повышение мощности на 15-20\% и крутящего момента на 25-30\%;

- снижение расхода топлива;

- очистка впуска, камеры сгорания, клапанов, поршней, турбины и свечей зажигания.

Минусы от применения впрыска воды:

- стоимость системы (окупается за один год эксплуатации автомобиля);

- необходимость периодически заправлять дополнительный бачок дистиллированной водой, метанолом или водометанолом. [4,5]

В нашей стране, еще очень и очень много карбюраторных автомобилей, владельцы которых заинтересуются данной темой, т.к. при этом повышается КПД ДВС, a, следовательно, и мощность, а, следовательно, снижается расход бензина. По разным источникам экономия топлива при подмесе воды составляет от 5 до 10\%. [2]

Для инжекции воды в камеру сгорания используют устройства, различающиеся системой питания двигателя (карбюратор и впрыск). Для этих целей был приобретен комплект Ecomax 3, состоящий из блока управления, насоса высокого давления, шланги подводки, форсунки, комплект проводов, штуцер бачка и компакт диск с программным обеспечением. 


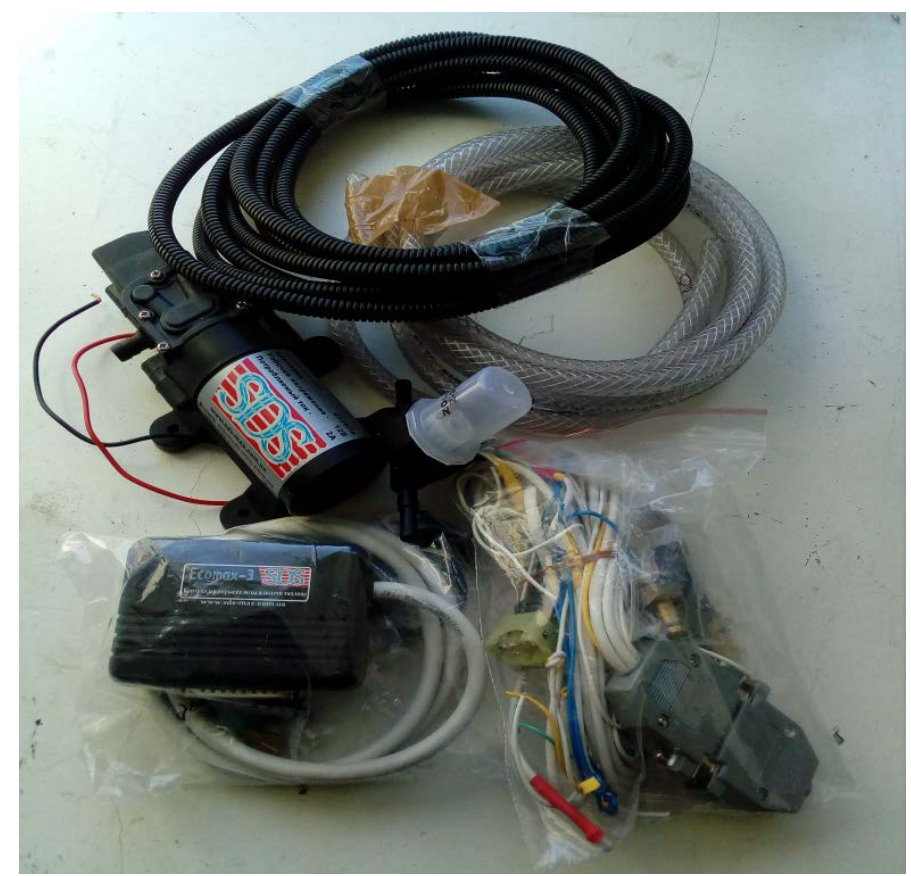

Рис 1. Устройство Есотах 3

По данным УГИБДД при МВД РС(Я) численность бензиновых автомобилей (декабрь 2018 г.) в республике составляет приблизительно 200 тысяч.

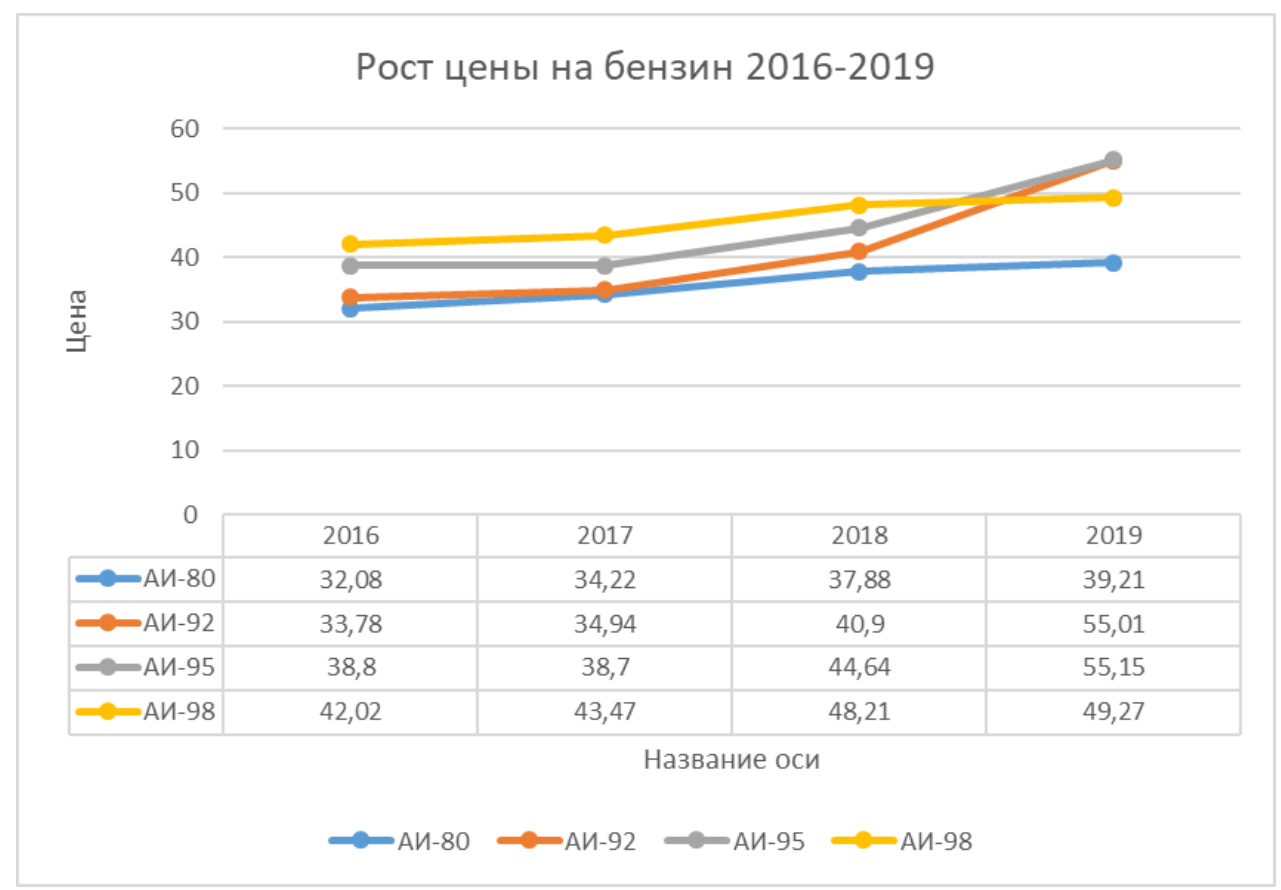

Рис 2. Динамика стоимости 1 литра бензина в городе Якутске (2016-19 г)

Большинство современных автомобилей «питается» бензином. Только представьте: одна тонна горючего в процессе сгорания выделяет до 800 кг вредных веществ! Но хуже всего, если двигатель работает на этилированном бензине. В таком случае, в воздух будет попадать свинец, который легко оседает и загрязняет почву. [7]

Проблема вредных выбросов автомобильного транспорта являются составной частью экологической безопасности. Эта проблема, связана с использованием традиционного моторного топлива в двигателях транспортных средств, актуальна не 
только для России, но и для всех стран мира. Автомобильный транспорт, генерирующий шум и загрязняющий атмосферный воздух, является одним из основных источников загрязнения окружающей среды в крупных городах и населенных пунктах, a также представляющих угрозу жизни человека. Поэтому мы заинтересовались снижением выбросов автомобильного транспорта в окружающую среду. [8]

В нашей республике основная масса автомобилей на бензиновом топливе относятся к экологическому классу от 1 до 3.

Используя устройство впрыска воды можно снизить количество вредных выбросов. По наблюдениям опытных водителей со стажем, при движении на автомобиле, во время и после грозы, наблюдается положительный эффект работы двигателя, что связано с высокой влажностью и насыщением озоном воздуха. Двигатель работает более равномерно и сбалансированно, следовательно, улучшаются его тягово-мощностные характеристики. Исходя из этого рекомендуется озонировать воздух, поступающий в камеру сгорания и использовать устройства, позволяющие расщеплять воду на отрицательно и положительно заряженные частицы.

\section{Заключение}

Технология впрыска воды в ДВС существенно повышает КПД автомобиля за счет увеличения мощностных и динамических характеристик, экономичности, улучшает экологические показатели выхлопных газов, а также отсутствие нагарообразования ведет к увеличению срока службы цилиндропоршневой группы.

\section{Список литературы:}

1. krutimotor.ru_Впрыск воды в двигатель: как сделать самому. [электронный pecypc]. - Режим доступа: http://krutimotor.ru/vprysk-vody-v-dvigatel/

2. rakarskiy.io.ua Впрыск паров воды в топливную смесь ДВС. [электронный ресурс]. - Режим доступа:

https://rakarskiy.io.ua/s482116/vprysk_parov_vody_v_toplivnuyu_smes_dvs

3. www.drive2.ru Впрыск воды в двигатель. Шарлатанство или изобретение века? [электронный ресурс]. - Режим доступа: https://www.drive2.ru/l/4899916394579309692/

4. mashintop.ru Впрыск воды в двс (двигатель внутреннего сгорания). [электронный https://mashintop.ru/articles.php?id=2918

5. jtlab.ru Система впрыска воды в двигатель внутреннего сгорания. [электронный pecypc]. - Режим доступа: https://jtlab.ru/blog/water-injection-system

6. biblioclub.ru Дружинин. Модернизация двигателей внутреннего сгорания [электронный pecypc].

Режим доступа: https://biblioclub.ru/index.php?page=book_view_red\&book_id=466777

7. legkopolezno.ru Легко полезно. Влияние разных видов транспорта на экологию: цена комфорта [электронный ресурс]. _ https://legkopolezno.ru/ekologiya/prostranstvo-vokrug-nas/vliyanie-transporta-na-ekologiyu/

8. nsportal.ru Алые паруса. Влияние автомобильного транспорта на окружающую среду и жизнь человека [электронный ресурс]. - Режим доступа: https://nsportal.ru/ap/library/nauchno-tekhnicheskoe-tvorchestvo/2013/04/06/vliyanieavtomobilnogo-transporta-na 